\title{
Prospect theory and the effects of bankruptcy laws on entrepreneurial aspirations
}

\author{
Saul Estrin • Tomasz Mickiewicz • Anna Rebmann
}

Accepted: 17 October 2016 / Published online: 26 December 2016

(C) The Author(s) 2016. This article is published with open access at Springerlink.com

\begin{abstract}
We apply prospect theory to explain how personal and corporate bankruptcy laws affect risk perceptions of entrepreneurs at time of entry and therefore their growth ambitions. Previous theories have reached ambiguous conclusions as to whether countries with more debtor-friendly bankruptcy laws (i.e. laws that are more forgiving towards debtors in bankruptcy proceedings) are likely to have more entrepreneurs, or whether, creditorfriendly regimes have positive effects on new ventures via enhanced incentives for the supply of credit to entrepreneurs. Responding to this ambiguity, we apply prospect theory to propose that entrepreneurs do not attach the same significance to different elements of bankruptcy codes - and to explain which aspects of debtor-friendly bankruptcy laws matter more to entrepreneurs. Based on this, we derive and confirm hypotheses about the impact of aspects of bankruptcy codes on entrepreneurial activity using the Global Entrepreneurship Monitor combined with data on both personal and corporate bankruptcy regulations for 15 developed OECD countries. We use multilevel random coefficient logistic regressions to take account of the hierarchical nature of the data (country and
\end{abstract}

The order of the authors is alphabetical.

S. Estrin

London School of Economics, Houghton Street, London WC2A

2AE, UK

e-mail: s.estrin@1se.ac.uk

T. Mickiewicz $\cdot$ A. Rebmann $(\bowtie)$

Aston University, Aston Triangle, Birmingham B4 7ET, UK

e-mail: t.mickiewicz@aston.ac.uk, a.rebmann@aston.ac.uk individual levels). Because entrepreneurs and creditors are sensitive to different elements of the codes, there is scope for optimisation of the legal design of bankruptcy law to achieve both an adequate supply of credit and to encourage high-ambition entrepreneurship.

Keywords Entrepreneurship · High-aspiration entrepreneurship · Bankruptcy · Global entrepreneurship monitor

JEL classification $\mathrm{L} 26 \cdot \mathrm{K} 22 \cdot \mathrm{D} 810$

\section{Introduction}

"Holland, the most unpolite country in the world, uses debtors with mildness and malefactors with rigour; England, on the other hand, shows mercy to murderers and robbers, but of poor debtors impossibilities are demanded." Samuel Byrom, Manchester Times 22 October 1862

The importance of formal institutions in shaping incentives and behaviour is now widely accepted. In particular, it has been recognised that the institutional environment is a crucial factor affecting entrepreneurship (e.g. Baumol 1990; Busenitz et al. 2000; Levie et al. 2014). Previous researchers have stressed the role of both 'higher order' institutions (e.g. constitutional protection of property rights) and of government regulations (e.g. Djankov et al. 2002; Klapper et al. 2006; van Stel et al. 2007; McMullen et al. 2008; Bowen and De Clercq 2008; Sobel 2008; 
Levie and Autio 2011; Troilo 2011; Aidis et al. 2012; Estrin et al. 2013, 2016). We posit that bankruptcy procedures are a feature of a nation's institutional environment at the regulatory level and have special significance for entrepreneurship (Dally 1994; McGrath 1999; Lee et al. 2007).

Legal arrangements for bankruptcy are critical for entrepreneurship as they form 'the rules of the end game' (Lee et al. 2011, p. 519); that is the mechanisms to deal with business failure. Entrepreneurship is risky with low survival rates (Audretsch 1991; Mata and Portugal 1994; Geroski 1995; Gimeno et al. 1997). Although firm closure does not necessarily mean that the business has failed, business failure is a common outcome of entrepreneurship (Headd 2003; Wennberg et al. 2010) and also one about which potential entrepreneurs are especially concerned when making entry decisions (Dew et al. 2009).

In previous literature, researchers theorise that countries where bankruptcy laws are more debtor friendly, i.e. are more forgiving towards debtors in bankruptcy proceedings, are likely to have more entrepreneurs (Lee et al. 2007, 2011; Armour and Cumming 2008; Peng et al. 2010). This is because entrepreneurship theory emphasises the role of entrepreneurs in creating value by taking risks in innovating, investing and launching new ventures (e.g. Foss and Klein 2012). Debtor-friendly regimes are seen to reduce the downside risks to failure and thus make entering entrepreneurship more attractive (Lee et al. 2007, 2011; Armour and Cumming 2008; Peng et al. 2010). However, the overall effect on entrepreneurship is ambiguous because debtor-friendly bankruptcy regimes take rights away from creditors, unlike more creditor-friendly bankruptcy law that encourages the provision of finance and may thereby relax financing constraints for entrepreneurs (Shleifer and Vishny 1997; Djankov et al. 2007). Indeed, Lee et al. (2011) and Lee and Yamakawa (2012) find that only some elements of debtor-friendly corporate bankruptcy law are positively linked to new firm entry rates. Yet they do not offer an explanation as to why certain elements of bankruptcy law do encourage entrepreneurship while others do not. This is our opening research question.

We add to the literature in three ways. First, by offering a theory-based rationalisation and empirical test, we aim to resolve the ambiguity of the effect of bankruptcy law identified above. We use prospect theory to offer an explanation as to which elements of bankruptcy law will be salient to entrepreneurs and which ones less so, when potential entrepreneurs evaluate their risks at the point of entry.
Second, we provide empirical analysis of the effects of both personal and corporate bankruptcy law. Until now, empirical studies of the relationship between bankruptcy law and entrepreneurship have focused on either personal or on corporate bankruptcy law but not both together and there has been a debate on the relevance of the latter to entrepreneurs (Cumming 2012; Lee and Yamakawa 2012).

Third, we extend previous studies by distinguishing between high-growth aspiration entrepreneurs and those entrepreneurs who aspire only to create jobs for themselves or their families. As Henrekson and Sanandaji (2014) and Levine and Rubinstein (2013) have stressed, more ambitious forms of entrepreneurial activities, which are central to innovation, growth and development, are not well measured by generic indicators of self-employment or new firms creation; thus, the distinction between the aspiration levels is important (see also: Wong et al. 2005; Henrekson and Johansson 2010; Levie and Autio 2011; Estrin et al. 2013). As recently demonstrated by Stephan et al. (2015), ambition and growth aspirations are the most important factors for business success. Previous literature on the impact of bankruptcy regulations has ignored the distinctions between the levels of aspiration; we argue this distinction is important because the influence of bankruptcy procedures will vary according to growth aspirations.

We derive hypotheses based on prospect theory of how elements of country-specific regulatory arrangements concerning personal and corporate bankruptcy law affect the likelihood of individuals starting a new venture. We test our hypotheses using data from the Global Entrepreneurship Monitor combined with data on personal and corporate bankruptcy regulations for 15 developed OECD countries. We apply multilevel random coefficient logistic regressions which take into account the hierarchical nature of the data (country and individual levels).

We find that both personal and corporate bankruptcy law affect entrepreneurs: whilst personal bankruptcy law influences a broad range of entrepreneurs, corporate bankruptcy law impacts on ambitious entrepreneurs. We argue that prospect theory helps to explain which elements of bankruptcy law will influence the prevalence of entrepreneurship. This allows us to derive important recommendations about the optimum design of bankruptcy law. We argue that because creditors and entrepreneurs attach different significance to 
different elements of bankruptcy law, scope is left for improvement in the legal framework. In this way, we also contribute to the classic law and economics literature, probably best represented in the context of bankruptcy by Posner (2007).

\section{Prospect theory - a lens to understand how entrepreneurs view the downside risks of bankruptcy}

Expected utility theory is the standard approach to decision-making under uncertainty (Arrow 1971). However, Kahneman and Tversky (1979) have argued that this model does not capture the behaviour that we actually observe. In expected utility theory, alternative choices are evaluated according to the sum of the returns under different outcomes, each weighted by the probability of that outcome taking place. Yet, this view of decision-making under uncertainty does not account for the way that people's choices are influenced by all sorts of cognitive biases. For example, in expected utility theory, the utility of gaining US\$50 is equivalent to the loss of utility from losing US $\$ 50$. In experiments, this prediction is not supported.

Kahneman and Tversky (1979) have developed an alternative theory that is based more closely on observed behaviour: prospect theory (see Tversky and Kahneman 1992 for further advances in prospect theory, also Barberis and Thaler 2003). There are three fundamental propositions of prospect theory which, taken together, provide a framework which can be applied to improve our understanding of how entrepreneurs make decisions under uncertainty. ${ }^{1}$ The first fundamental proposition of prospect theory is that individuals view outcomes from decisions under uncertainty as gains or losses relative to a reference point. Individuals are more attuned to the evaluation of changes than of absolute magnitudes (Kahneman and Tversky 1979). The reference point usually corresponds to the status quo. This contrasts with expected utility theory, where an outcome is evaluated only on the final utility position, regardless the individual's starting point (Kahneman and Tversky 1979).

\footnotetext{
${ }^{1}$ A feature of prospect theory we do not discuss in detail is diminishing sensitivity in evaluation of potential changes in value, because this has no direct bearings for our research questions.
}

The second fundamental proposition of prospect theory is that '...losses loom larger than gains. The aggravation that one experiences in losing a sum of money appear to be greater than the pleasure associated with gaining the same amount' (Kahneman and Tversky 1979, p. 279). This again implies that the initial position matters, as both gains and losses are evaluated with respect to it; a phenomenon that Thaler (1980) labelled as 'endowment effect.'

The third key element of prospect theory is that the value of outcomes is assessed by decision weights rather than the probabilities used in expected utility theory. Decision weights differ from probabilities in that they take into account the fact that humans are bad at estimating probabilities. During decision-making processes, individuals tend to underweigh probabilities in the middle range and overweigh both outcomes that are considered near certain or very unlikely. This means that a shift in circumstances where certainty of no loss is replaced by even a very small probability of a significant loss may have significant impact on the subjective evaluation and weighting of that prospect. Likewise, a shift from a situation where some positive outcome is deemed impossible to a situation where it becomes possible may have large positive effect on assessment of the prospect (Kahneman 2011).

Although prospect theory has rarely been used hitherto for the theory of entrepreneurship, it is of particular relevance as it provides an empirically based framework to analyse how individuals make decisions in uncertain and risky situations (Parker 2009; Wennberg et al. 2010). For entrepreneurs, the taking of risks and a high likelihood of failure is inherent: 'if the manager takes no risks... this individual is no longer an entrepreneur' (Knight 2009 [1921], p. 21). Applying prospect theory in the case of an entrepreneur starting a new venture, we posit that the reference point corresponds to the entrepreneur's position at time of venture creation. Empirical evidence indicates that entrepreneurs do pay attention to reference points when making start-up decisions as they decide which projects to pursue by considering whether they can afford to bear the losses incurred if the project fails rather than choosing those which will yield the highest expected return as would be predicted by expected utility theory (Dew et al. 2009). Furthermore, we argue that loss should not only be defined by financial loss but also by restrictions on choice which would occur for an entrepreneur with loss of decision rights over their venture: as the theory of opportunity cost 
posits, any restriction of choice is equivalent to an additional cost (Buchanan 1979). Based on this approach, gains from entrepreneurship will be judged as any outcome that leads the entrepreneur to increase both their wealth and their choice range relative to the point at which they started the business and, correspondingly, losses as related to any relative decrease.

The idea that losses are of greater significance than gains to people making decisions under uncertainty has also been shown to be relevant in the context of entrepreneurial choice. When an entrepreneur is assessing his/her returns, the potential costs that may accrue if the enterprise fails will be weighted more heavily than the upside gains from success. This is in contrast with the expected utility framework, in which the gains and losses are equally balanced. Effectuation research has highlighted the principle of affordable loss as a heuristic that successful entrepreneurs use when starting new ventures (Sarasvathy 2001). Moreover, possible future losses are more likely to be a prominent factor in the start-up decision than the potential future upside because they may come sooner and are easier to calculate (Dew et al. 2009). Estimating potential gains requires assessment of future revenues, costs and risks - aspects outside of the entrepreneur's control and which are likely to be highly uncertain for new ventures, and especially for high growth ones. Losses are easier to calculate as they are based on the individual's current financial position and commitment to the potential venture - about which the entrepreneur is well informed. In line with this, empirical research demonstrates that losing personal assets is the major factor when assessing the degree of risk at time of entrepreneurial entry decision. These risks relate in particular to the possibility of losing home ownership (Fan and White 2003; Levie and Hart 2010).

Prospect theory has important implications for our understanding of the effects of bankruptcy law on entrepreneurship as the evaluation of future gains and losses probabilities will be contingent of the institutional arrangements of the country in which the entrepreneur operates. Legal arrangements for bankruptcy are an important example of institutions which alter the balance of entrepreneurial gains and losses because they govern the pay-outs to creditors and debtors in bad states of the world when the entrepreneur becomes unable to service its debts. Bankruptcy law can produce a partial insurance against the costs of failure because they limit the downside losses that an entrepreneur may face by providing a mechanism for the debtor to discharge their debts (White 2001; Lee et al. 2007; Posner 2007; Armour and Cumming 2008). But the degree of that partial insurance effect depends on detailed elements of bankruptcy law; the harshness and the exact nature of bankruptcy arrangements towards debtors will affect the entrepreneur's evaluation of bad outcomes. Hence, a better understanding of attitudes towards risk, which is provided by prospect theory, is critical for evaluating which elements of bankruptcy law are likely to be more salient in the decision to become an entrepreneur and especially one with high aspirations. Thus, prospect theory offers a framework for understanding why not all debtor-friendly aspects of bankruptcy law are equally important for potential entrepreneurs and therefore positively related to start-up activity. In the next section, we present in more detail how those aspects of bankruptcy systems differ.

\section{Bankruptcy law}

'Bankruptcy is precipitated by debt; a firm that never borrowed could not go bankrupt, unless burdened by involuntary debt, such as tort judgement' (Posner 2007, p. 431). The bankruptcy code sets out the processes for the debtor and creditors to follow when the debtor becomes insolvent. It provides a collective framework to enable the distribution of the assets of the debtor amongst relevant stakeholders: creditors, tax authorities, employees, and, in corporate bankruptcy, shareholders (White 2007). Importantly, bankruptcy law provides entrepreneurs with insurance enabling them to clear their debts rather than being liable until they are paid off. This limits the downside risks in case of failure (Lee et al. 2007; Posner 2007), and therefore has a critical impact on how entrepreneurs evaluate risks at the point of entry.

Indebted entrepreneurs may face bankruptcy under two distinct jurisdictions: personal bankruptcy law or corporate bankruptcy law. Under personal bankruptcy, the entrepreneur as an individual is personally liable for all of the firm's debts except for the exemptions that the personal bankruptcy law specifies. This will occur in the case of proprietorships, partnerships and when personal guarantees have been tied to loans. However, if an entrepreneur has incorporated their business, bankruptcy takes place under corporate bankruptcy law and all personal assets which are not linked to the 
firm are protected from creditors by limited liability. Indeed, the protections of limited liability are the main reason entrepreneurs decide to incorporate their firms. Yet, as Cumming (2012) points out, creditors often demand that entrepreneurs provide personal guarantees which are equivalent to 'contracting out' of the limited liability protection. Thus, bankrupt entrepreneurs who own incorporated firms will often face personal as well as corporate bankruptcy. Thus, it is important to consider the effects of both types of bankruptcy law on entrepreneurship. Moreover, they are likely to have different effects on different types of entrepreneurs. We argue below that while the influence of personal bankruptcy law is likely to be wider, corporate bankruptcy has a greater effect on more ambitious entrepreneurs.

The general conclusion from previous empirical studies of bankruptcy law is that countries that have more debtor-friendly bankruptcy systems encourage entrepreneurship because these institutions reduce the downside losses to entrepreneurs and make entry less risky (Fan and White 2003; Armour and Cumming 2008; Peng et al. 2010; Lee et al. 2011; Lee and Yamakawa 2012). Yet, as has been emphasised in the law and economics literature (La Porta et al. 1998; Djankov et al. 2007, 2008), the bankruptcy code also affects the incentives for the supply of credit. When bankruptcy arrangements are creditor-friendly, they incentivise debtors to repay their debts and give the creditors greater power to recover their loans in case of default. This reduces the net cost of debt financing and increases its supply. Empirical evidence links both the size of the credit market (La Porta et al. 1997; Djankov et al. 2007) and credit provision to small firms (Berkowitz and White 2004) with the degree to which creditor rights are protected through stricter bankruptcy law. If, as argued by Evans and Jovanovic (1989), entrepreneurial activity is credit constrained, then creditor-friendly bankruptcy arrangements will enhance entrepreneurial activity by relaxing the constraints on the supply of funds (Parker 2009). The impact of this increased supply of funds is likely to be especially important for high-aspiration entrepreneurs since their demand for external finance is greater and the wider availability of finance for entrepreneurship at the country level facilitates the growth-aspiring entrepreneur's ability to raise funds to expand their business. This suggests that the individual likelihood of entrepreneurial entry may be positively related to elements of the bankruptcy code that enhance the return of debt in the case of business failure.
Previous research has considered both sides of the debate (Lee et al. 2011), but was limited in providing theory to help in understanding which aspects of bankruptcy law matter more to entrepreneurs and which to creditors. We propose that the elements of the bankruptcy law that matter most for entrepreneurs may not be those that matter most for creditors, and that prospect theory is a useful framework to unpick this issue. When starting a new venture, entrepreneurs will have invested some resources and are likely to have full control. They are also likely to have some personal resources and rights, which are not related to the venture. This is the entrepreneur's current position. In prospect theory terms, this is the reference point (endowment) from which they assess the potential losses in the event of failure. Thus, a loss for the potential entrepreneur would be a loss of the resources invested in the firm, loss of control of the firm and loss of other non-venture related personal resources and control rights. The second element of prospect theory, loss aversion, means potential loss weighs more heavily in the mind of the potential entrepreneur than the possible gains. Hence, the potential losses from downside risk loom larger in the decision to start a business. Elements of bankruptcy law that will affect the entrepreneur's decision to start a new venture most are therefore those that relate to personal assets of the entrepreneur and to restrictions on his/her decision rights.

\section{Hypotheses}

\subsection{Hypotheses: personal bankruptcy}

As explained above, under personal bankruptcy law, entrepreneurs are personally responsible for the firm's debts. Posner (2007) argues that the exemptions provided by personal bankruptcy law offer a type of insurance that would be difficult to provide via the market. Moreover, unlimited liability would imply 'heavy cost in supervising the collection of the bankrupt debts over his lifetime' (ibid., p. 436). For that reason, the law does not allow any person to 'waive his right to seek discharge of the debt in bankruptcy' (ibid.). On the other hand, personal bankruptcy law that comes with no cost to the debtor makes default an attractive option, leading to moral hazard. This may raise the interest rate or lead to credit rationing to compensate for the additional risk (Berkowitz and White 2004). The tension between these 
two aspects implies that optimising the design of personal bankruptcy law is non-trivial.

Lawmakers typically seek a compromise in which some costs to the debtors are balanced by some degree of protection. In most cases, and in all advanced economies, some form of personal bankruptcy procedure is available but the degree of protection offered to the debtor varies. In the previous literature, it has been theorised that more debtor-friendly personal bankruptcy regimes encourage more entrepreneurship (Armour and Cumming 2008). Yet, this gives no guidance to policy makers on which trade-offs to make. Here, prospect theory helps, as it suggests that the elements of personal bankruptcy law that will matter more to potential entrepreneurs and will have more influence on their decision to enter into entrepreneurship are those which relate to protecting their personal assets from downside losses. Next, we examine three elements of personal bankruptcy law: the availability of a fresh start, exemptions, and ability to reach a compromise with creditors. Using prospect theory, we propose hypotheses as to which elements are the most salient for potential entrepreneurs.

First, the most frequently discussed aspect of personal bankruptcy law as regards entrepreneurship is the availability of a 'fresh start', which generally allows the debtor 'an opportunity to begin a new and unencumbered financial chapter in his or her life' (Efrat 2002, p. 82). This involves both the debt being forgiven, or discharged, and the minimisation of other forms of discrimination. Countries vary according to the degree to which they allow a fresh start (Armour and Cumming 2008). At one (rare) extreme, personal bankruptcy law does not exist or, if it does, the discharge of debts is not available as part of the process (ibid.). At the other extreme, where a fresh start is available, debtors are automatically discharged of their debts after a certain period of time. Furthermore, no other restrictions are placed on the debtor's civic or economic rights (Armour and Cumming 2008; Efrat 2002). In other countries, the discharge may be available but it is not automatic. The debtor needs to apply to obtain discharge and even after application, it may not be given. Additionally, in some countries, other restrictions are imposed on the debtor's economic and civil rights until they are discharged from bankruptcy (Efrat 2002). These can range from being barred from obtaining credit, running a business, running for political office, to being incarcerated (Armour and Cumming 2008).
Second, exemptions of personal assets from the bankruptcy proceedings are also an important part of personal bankruptcy law (White 2007). Exemptions relate to personal assets owned at the start of bankruptcy that can be withheld and so, not be the subject of creditors' claims. Exemption levels vary across countries. Under generous bankruptcy law, the debtor's home may be exempt (Fan and White 2003). In most European countries, minimal exemptions apply — only tools of the trade and personal items are exempt (Armour and Cumming 2008). Moreover, in some countries, there are negative exemptions whereby a spouse's assets can be pulled into the bankruptcy proceedings (ibid.).

Third, personal bankruptcy codes differ in how difficult they make reaching a compromise with the creditors whereby the debtor can agree with creditors to pay a proportion of the face value of the debts and for the rest to be discharged (Armour and Cumming 2008). Compromise with creditors is useful either when automatic discharge is not available or when the debtor wishes to exit bankruptcy sooner than the automatic discharge period. The ease of securing a compromise depends, in particular, on whether the majority of creditors is allowed to overrule the minority in reaching an agreement with the debtor (ibid).

How significant are these three aspects for an entrepreneur when evaluating their risks on the basis of prospect theory? This theory leads us to expect that the lack of a fresh start, which means the possibility of losing pre-existing rights, both economic and civic, including a right to start another business afresh, and the lack of exemptions on key pre-existing assets, especially the family home, will feature high on the list of risks when deciding whether to engage in (ambitious forms of) entrepreneurship as these are freedoms and assets that the entrepreneurs have at the time of starting a business. Thus, these provisions of personal bankruptcy law increase the perceived potential for loss compared to the reference point, and loss aversion will discourage individuals from starting a business.

Assuming that entrepreneurs rely on decision weights, not actual probabilities, can explain why movement from bankruptcy systems where entrepreneurs are protected through fresh start and exemptions and face no probability of losing their initial rights or collateral, to one where these protections are removed, may induce a dramatic change in the entrepreneur's evaluation of the prospect to start a project. The change in probability of losing these rights and collateral would look small when 
evaluated in terms of expected utility, but the impact on how the entrepreneur evaluates the prospects may actually change dramatically. For example, in the USA or UK, where collateral is often based on home ownership, evaluations of bad outcomes may be significantly altered in contexts where that home is exempted from creditors' claims (Fan and White 2003). On the other hand, prospect theory leads us to expect that the potential difficulty in arriving at a compromise with creditors, while important as a sanction for creditors, will be of little significance to the entrepreneur at the time they are deciding whether to start a venture or not. This is not an element that links directly to their conditions at time of entry (i.e., their reference point), and therefore it will be given less weight. Based on this, we posit:

Hypothesis 1 The likelihood of an individual becoming a high growth aspiration entrepreneur is lower in countries where the bankruptcy codes offer:

(a) No fresh start, i.e. no discharge available after personal bankruptcy and restrictions are imposed on debtor after bankruptcy,

(b) Fewer exemptions of personal assets from creditors' claims on the debtor.

\subsection{Hypotheses: corporate bankruptcy}

Corporate bankruptcy law allows distressed incorporated firms to resolve their debts and constitutes a mechanism for firm's exit in the case of business failure (White 2007). Given that corporate bankruptcy law only applies to limited liability companies, it is unlikely that the severity of the law will affect all entrepreneurs equally. Self-employed entrepreneurs and those with lower growth aspirations are less likely to register their firms as limited liability corporations because the costs of registering - such as having to adhere to corporate regulation and pay corporate income tax-may be greater than the benefits (Klapper et al. 2006). In contrast, entrepreneurs who have ambitions to grow and employ others are much more likely to adopt the limited liability form and therefore become affected by corporate bankruptcy law, especially as to achieve high growth, they are likely to need to take on debt. These entrepreneurs benefit, therefore, from the greater protection from bankruptcy provided through limited liability (Vanacker and Manigart 2010).
Generally, corporate bankruptcy law includes two types of procedures to deal with insolvent firms: liquidation and reorganisation (La Porta et al. 1998; Armour 2001). Liquidation occurs when a firm is converted into cash through the sale of its assets (Hart 2000; Armour 2001). In liquidation, the entrepreneur is separated from the firm. In contrast, reorganisation allows the entrepreneur a second chance as an insolvent debtor company is allowed to continue operating and is given additional time to devise a reorganisation plan (La Porta et al. 1998). The aim of reorganisation is to aid firms in becoming solvent again while the burden of current debt is lifted.

Although these two procedures, liquidation and reorganisation, are generally available in most bankruptcy regimes, there is enormous variation in the specific details of each procedure. As is the case with personal bankruptcy, this heterogeneity is in part due to conflicting objectives of the legislation: seeking to protect creditor rights against preventing the liquidation of viable firms leading to the loss of jobs (Claessens and Klapper 2005). Bankruptcy law in different countries strikes different balances between offering guarantees to creditors and creating opportunities for retaining control by owners-managers. Our approach is to use prospect theory to identify which individual components of corporate bankruptcy law will affect entrepreneurs, also paying attention to the fact that only entrepreneurs with high levels of growth aspirations are likely to be affected. We propose that the effect of each component of bankruptcy law on entrepreneurs' motivation depends on how it addresses the alleviation of those risks which matter most for entrepreneurs.

As a preliminary step, to identify the components of corporate bankruptcy law, we concentrate on La Porta et al.'s (1998) creditor rights' index to characterise national bankruptcy regimes. Here, the power given to creditors is assessed by the presence of four crucial elements of creditors' rights: priority to secured creditors in the distribution of assets, a debtor's right to choose reorganisation, the absence of stays on secured assets and mandatory removal of management. We will next discuss the expected impact of these four elements.

We do not anticipate a negative impact on highaspirations entrepreneurship if there are restrictions on filing for reorganisation such as requiring creditors' consent or minimum dividends. Extant literature categorises reorganisation as a debtor-friendly process because it gives a chance for the firm to survive 
bankruptcy proceedings and for the owners to retain control of the organisation after bankruptcy (La Porta et al. 1998; Lee et al. 2007). Yet, by strengthening the position of creditors, restrictions on reorganisation may enhance the supply of credit because secured creditors are more likely to be able to recover the value of their loans through liquidation rather than going through the uncertain and often lengthy reorganisation process (La Porta et al. 1998; Prentice et al. 2003). ${ }^{2}$ At the same time, from the perspective of prospect theory, there are no obvious disincentive effects on high aspiration entrepreneurs from either of these arrangements; these do not represent the potential losses of the entrepreneur as evaluated with respect to his/her initial position at the time of start-up decision. Thus, we do not hypothesise any effect of restrictions on reorganisation on highaspiration entrepreneurship.

We also do not expect that high-aspiration entrepreneurship will be negatively impacted by corporate bankruptcy codes which give priority to secured creditors in the distribution of the assets of a bankrupt firm. There is no element of prospect theory we could use to explain how it could affect the entrepreneurial choice at the time of entry decision.

In contrast, we posit that the dimensions of a bankruptcy code that matter for the entrepreneur are (a) no automatic stay on secured assets and (b) requirement concerning the removal of the incumbent management. These two elements of bankruptcy law influence the extent to which the entrepreneur is able to remain in control if the firm enters into reorganisation proceedings. In some countries, such as the USA, the legal provisions for reorganisation shift the balance of power from creditors to debtors allowing the entrepreneur to remain in control of their firm during bankruptcy (Pochet 2002). In others, such as the UK, this shift of power does not occur, which limits the use of reorganisation instead of outright liquidation. This loss of power is important to entrepreneurs because they strongly value control of their companies (Parker 2009) and, as we argued above, endowment in control rights is akin to endowment in wealth. Importantly, these decision rights are not gained with the development of the venture but are present from the outset, representing an initial endowment; hence, prospect

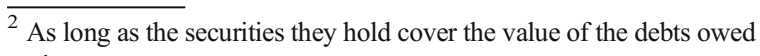
to them.
}

theory suggests that the risk of losing them should feature highly in an entrepreneur's considerations.

Where the removal of the incumbent management during reorganisation is required, management is replaced by an external party. For example, in the UK, the management must be replaced by an official administrator appointed by the secured creditors. The administrator will then run the business and prepare the reorganisation plan. In other countries, the incumbent management may remain in control of the firm, for example, in the USA under Chapter 11. Brouwer (2006) argues that ousting of management during bankruptcy proceedings is a crucial factor in explaining why fewer firms survive bankruptcy intact through reorganisation in Europe than in the USA. Given prospect theory, required removal may have an especially strong negative impact on high-aspiration entrepreneurs because of the loss of control it entails. Furthermore, the automatic removal of the incumbent manager can have, at best, modest implications for the return to creditors, as the potential disciplining effects on entrepreneurs are counterbalanced by the fact that their idiosyncratic knowledge and motivation with respect to their venture may help them to restore the viability of the company, especially that financial distress could be caused by unexpected temporary external shocks.

Next, in some countries, an automatic stay is also placed on secured assets during reorganisation proceedings. This prevents secured creditors from unilaterally seizing the firm's assets that they hold as security, thus allowing time for the implementation of a reorganisation plan. In most cases, the assets used for security will be important to the running of the business, and the firm may be therefore unable to continue in business if the option of unilateral seizure is executed. This is likely to have a disincentive effect on entrepreneurs: again, according to prospect theory, an increased risk of losing control rights over their venture should have a major impact at the time of start-up decisions, as these control rights are present from the beginning. Additionally, the place of an automatic stay can have beneficial effects for creditors as without it, the threat of other creditors unilaterally seizing assets may encourage creditors into a 'race to collect' the debts owed to them (Armour 2001). Thus, if no automatic stay is placed on assets, the likelihood of a firm surviving bankruptcy as a going concern will be reduced and some creditors may not get anything. Combining together an evaluation of all four characteristics of corporate bankruptcy codes leads us to propose: 
Hypothesis 2 The likelihood of an individual becoming a high-growth aspiration entrepreneur is lower in countries where the removal of incumbent management is mandatory during the reorganisation process, and there is no automatic stay on secured assets.

\section{Methods}

\subsection{Data}

Our data on entrepreneurial aspirations and individual characteristics derive from the Global Entrepreneurship Monitor (GEM) adult population surveys (Reynolds et al. 2005). We have at our disposal data from 15 OECD countries covering 450,954 individuals over the years 1999-2005 which form a pooled, cross-sectional, time series dataset; however, due to missing data on specific variables, the actual number of observations we use in estimations is 255,275 . This time period and the number of countries included in the sample were chosen due to data availability as explained in the next section. The GEM survey started in 1999 with representative samples of 1000 individuals within in each country. From 2000 onwards, the data consist of representative samples of at least 2000 individuals in each country, although some country teams were able to finance larger samples. GEM surveys were completed through phone calls, and through face-to-face interviews in countries where low density of the telephone network could create a bias. National datasets are harmonised across all countries included in the survey. The dataset is unbalanced as information is not available for all countries in all years. Each year, the survey comes from a different sample of respondents. The samples are drawn from the working age population, which avoids the potential selectivity bias that could affect studies which focus on existing entrepreneurs.

Data on personal bankruptcy law are taken from Armour and Cumming (2008). They provide a crosscountry comparison of personal bankruptcy law in 15 OECD countries. Data on corporate bankruptcy law in each country derive from Djankov et al. (2007) (see also La Porta et al. 1998). They provide a cross-country comparison of the rights of creditors to extract a return through corporate bankruptcy proceedings. The data on bankruptcy law are only available until 2005 which limits the number of years available for analysis.

\subsection{Dependent variables}

We use a sequence of four dependent variables to measure nascent entrepreneurship. Nascent entrepreneurs are defined by GEM as individuals between the ages of 16 and 64 who, in the past year, have taken action towards setting up a business that they expect to own, but who are yet to have paid anyone wages for more than 3 months (Bosma and Levie 2009). Our first dependent variable, start-up, measures whether an individual is engaged in starting a new business. It takes a value of 1 for those who are in the process of starting a business and 0 for those who are not. However, we are particularly interested in distinguishing the effect of bankruptcy law on high-aspiration nascent entrepreneurs. Following Estrin and Mickiewicz (2011), we create a series of variables which are nested within the start-up category and distinguish different levels of growth aspirations. Data on growth aspirations is gathered in GEM through the question 'How many people will be working for this business, not counting the owners but including all exclusive subcontractors, when it is five years old? By exclusive subcontractors, we mean people or firms working only for this business, and not working for others as well' (Reynolds et al. 2005). High asp 5 is coded 1 when an individual indicates that they are nascent entrepreneur who aspires to employ more than five people in 5 years. A value of zero is given to all other respondents; hence, the zero category contains both non-nascent entrepreneurs and those with low growth aspirations. The same logic applies to the creation of high asp 10 and high asp 20 only in the case for the former the nascent entrepreneur must aspire to have 10 or more employees in 5 years and for the latter 20 employees. Thus, these variables are nested one inside the other, meaning, for example, that individuals categorised as a high asp 20 entrepreneur, aspiring to create more than 20 jobs in 5 years will also be categorised as a high asp 10 and high asp 5 entrepreneur, but not vice versa. Figure 1 below illustrates how the variable was constructed. This approach is useful because we are able to utilise the whole sample so Heckman selection models are not needed and as the nesting of the dependent variables means that the four equations estimated using these dependent variables do not require simultaneous estimation.

In addition to the four regressions based on the nested categories of start-up as described above, we alternatively combined the start-up categories into one ordered 


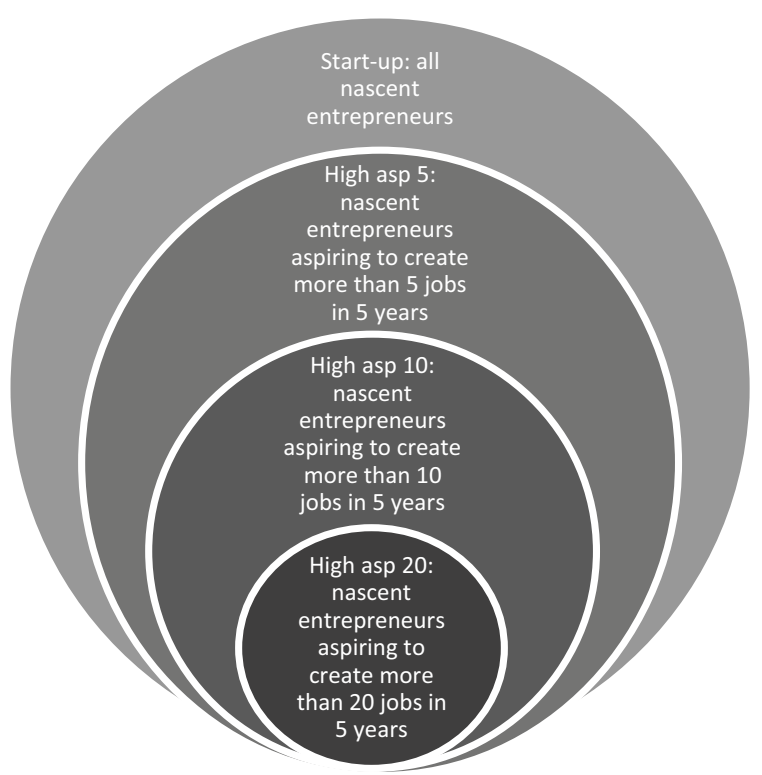

Fig. 1 Construction of nested dependent variables

variable. Accordingly, individuals not engaged in entrepreneurship are coded as 0 ; individuals are coded as 1 if they are engaged in nascent entrepreneurship but with no aspirations to employ more than 5 people in 5 years; as 2 if in the next 5 years they aspire to employ more than 5 and up to 10 employees in; as 3 if they aspire to employ between 10 and 20 employees and as 4 if they aspire to employ 20 or more employees.

\subsection{Explanatory variables}

\subsubsection{Personal bankruptcy law}

Armour and Cumming (2008) have compiled measures of the severity of personal bankruptcy law in 15 countries in Europe and North America for the years 1990 to 2005 , though for consistency with the starting point of our entrepreneurship data (GEM dataset), we will only use the data from 1999. ${ }^{3}$ The key dimensions of personal bankruptcy identified by Armour and Cumming (2008) are:

- No discharge from personal indebtedness is available after bankruptcy $=1 ;=0$ otherwise;

- Restrictions on the debtor (disabilities) are imposed after bankruptcy, and these restrictions may relate to

\footnotetext{
${ }^{3}$ The countries in our sample are Austria, Belgium, Canada, Denmark, Finland, France, Germany, Greece, Ireland, Italy, Netherlands, Spain, Sweden, UK, and USA.
}

his/her civic and economic rights over the bankruptcy period; the variable takes a value between 0 and 4 ;

- Exemptions of personal assets $=1$ if debtors can only keep modest personal items and tools and equipment; $=0$ if more generous exemptions allowed (e.g. homestead exemptions in USA);

- Compromise with creditors difficult measures how difficult it is for debtors to reach a compromise with creditors to end bankruptcy proceedings. ${ }^{4}$ This varies according to how the majority voting requirement is formulated regarding number of creditors and the value of claims. The variable measures this on continuous scale by adding the required proportion of debtors to the required proportion of claims' value, resulting in a range varying between 0 and 2 .

For all variables, a higher value indicates less debtorfriendly personal bankruptcy law. Correlations between these four indicators are relatively low (between 7 and $24 \%$ ), with one important exception of the correlation between restrictions on debtor and no discharge. Since these both link to the availability of a fresh start and the restriction debtors' rights, it is unsurprising that they are typically applied jointly. However, this also makes estimation with both elements present difficult due to multicollinearity. In order to address this problem, in our estimations, we add these two dimensions together to create a single-scale fresh start which takes values of 0 to 6 with higher values indicating more barriers to a fresh start and a less debtor-friendly bankruptcy law. We verified the reliability of this two-component scale reliability and the Cronbach's alpha coefficient was reasonable at 0.63 . This leaves us with three variables for personal bankruptcy law: fresh start, exemptions of assets, and compromise with creditors difficult.

\subsubsection{Corporate bankruptcy law}

The literature on corporate bankruptcy law has developed from La Porta et al.'s (1998) creditor rights index comprising four elements in bankruptcy proceedings that can be compared across countries and which, taken together, shift the balance of power from debtors to creditors. These four measures are:

\footnotetext{
${ }^{4}$ This variables is called composition in Armour and Cumming (2008).
} 
- Secured creditors first $=1$ if priority is given to secured creditors in the distribution of the proceeds that result from the disposition of the assets of a bankrupt firm;

- Restrictions on reorganisation $=1$ if there are restrictions for filing for reorganisation such as requiring creditors' consent or minimum dividends;

- No automatic stay $=1$ if there is no automatic stay on secured assets during reorganisation;

- Management goes $=1$ if there is mandatory removal of the incumbent management from control of the firm during reorganisation proceedings.

The creditor rights index, which has been widely used in the empirical literature, is constructed by aggregating and equally weighting these four components of a country's corporate bankruptcy law into a simple index (e.g. La Porta et al. 1998; Djankov et al. 2007, 2008). The more of these rules are present in a country, the more the bankruptcy law is regarded as creditorfriendly, and the less as debtor-friendly (Djankov et al. 2007, 2008; Lee et al. 2007, 2011; Peng et al. 2010; Cirmizi et al. 2011). Giving power to creditors has been seen in this literature as being unfriendly to entrepreneurs since it increases the downside risks for entrepreneurs as failure is likely to lead to harsher consequences for the entrepreneur (Lee et al. 2007, 2011; Peng et al. 2010).

Although the creditor rights index is a pioneering measure of bankruptcy law across countries, we doubt if it is always appropriate to aggregate the individual bankruptcy rules. Indeed, most of the correlations between the four elements of bankruptcy law are very low, ranging from virtually zero to $12 \%$. Cronbach's Alpha for the four items is 0.48 , which does not support the construction of the single index. Other research also suggests that the complexities of corporate bankruptcy law are not accurately captured by the single index. Claessens and Klapper (2005) find no associations between the use of corporate bankruptcy law across countries and the index, while there are significant associations when they disaggregate the index into its components. As we argued in the hypothesis section above, not all elements of bankruptcy law matter equally to entrepreneurs. Therefore, we follow Claessens and Klapper (2005) in disaggregating the La Porta et al. (1998) index into its constituent parts. One important exception we made, however, is due to the high correlation of 0.67 between the two dimensions that we identified as most related to the issue of entrepreneurial control: management goes and no automatic stay on assets.

To address this multicollinearity, we merge no automatic stay on assets and management goes. Cronbach's alpha scale reliability coefficient for this combined measure is high at 0.90 . We use the three resulting variables (two individual index components and a scale combining the two other components) to represent corporate bankruptcy regulations in our regression analysis. As with personal bankruptcy code elements, for all variables, a higher value indicates a less debtor-friendly bankruptcy law.

Bankruptcy variables are available until 2005 (Djankov et al. 2007), while entrepreneurship variables from GEM are available from after 1999, so these two time points define the period over which we can estimate. For compatibility we use the same 15 countries as for personal bankruptcy estimations. See Table 1 below for a summary of each country's bankruptcy law over time.

\subsection{Control variables}

\subsubsection{Individual level: sociodemographic characteristics}

We include standard individual level controls for sociodemographic characteristics such as gender, age, work status at time of the start-up, education, and income in all models as they have been shown to be significantly related to entrepreneurial entry and aspirations (Parker 2009; Reynolds 2010; Estrin and Mickiewicz 2011; Aidis et al. 2012). Gender (female) is coded 1 for females. Age is included with $\operatorname{age}^{2}$ as an inverted U-shaped relationship with entrepreneurial entry has been previously identified (e.g. Levesque and Minniti 2006). Education is controlled for by two dummy variables: secondary education indicates whether an individual has completed secondary education (coded as 1) and higher education, which indicates whether an individual has completed higher education (also coded as 1). The third educational category is omitted benchmark, it represents primary education. We also include six GEM categories representing work status (see Table 2 below), with full employment representing benchmark. In addition, in line with studies cited above, we add business angel dummy, which represents an 
Table 1 Summary of bankruptcy law measures

\begin{tabular}{|c|c|c|c|c|c|c|c|}
\hline \multirow[b]{2}{*}{ Country } & \multirow[b]{2}{*}{ Years } & \multicolumn{3}{|c|}{ Personal bankruptcy law } & \multicolumn{3}{|c|}{ Corporate bankruptcy law } \\
\hline & & $\begin{array}{l}\text { Fresh start } \\
\text { (no discharge } \\
+ \text { restrictions) }\end{array}$ & $\begin{array}{l}\text { Exemptions } \\
\text { on personal } \\
\text { assets }\end{array}$ & $\begin{array}{l}\text { Compromise } \\
\text { with creditors } \\
\text { difficult }\end{array}$ & $\begin{array}{l}\text { Secured } \\
\text { creditors } \\
\text { first }\end{array}$ & $\begin{array}{l}\text { Restrictions } \\
\text { on } \\
\text { reorganisation }\end{array}$ & $\begin{array}{l}\text { No automatic } \\
\text { stay and } \\
\text { management } \\
\text { goes }\end{array}$ \\
\hline USA & 1999-2005 & 1 & 0 & 1 & 1 & 0 & 0 \\
\hline Greece & 2003-2005 & 4 & 1 & 1.46 & 0 & 1 & 0 \\
\hline Netherlands & $2002-2005$ & 0 & 2 & 1 & 1 & 0 & 2 \\
\hline Belgium & $2000-2005$ & 3 & 1 & 1 & 1 & 0 & 1 \\
\hline France & $2000-2005$ & 2.5 & 2 & 0 & 0 & 0 & 0 \\
\hline \multirow[t]{2}{*}{ Spain } & 2002-2004 & 4 & 1 & 1.1 & 0 & 0 & 2 \\
\hline & 2005 & & & 0.5 & 1 & & \\
\hline Italy & 1999-2005 & 4 & 1 & 1.16 & 0 & 1 & 1 \\
\hline Austria & 2005 & 0 & 2 & 1.25 & 1 & 1 & 1 \\
\hline UK & $2000-2005$ & 2 & 1 & 1 & 1 & 1 & 2 \\
\hline Denmark & 1999-2005 & 3.5 & 1 & 1.4 & 1 & 0 & 2 \\
\hline Sweden & $2000-2005$ & 3 & 1 & 2 & 1 & 0 & 0 \\
\hline \multirow[t]{2}{*}{ Germany } & 1999 & 4 & 0 & 1.25 & 1 & 0 & 2 \\
\hline & $2000-2005$ & 1 & & 1 & & & \\
\hline Canada & 1999-2005 & 2 & 0 & 1.16 & 1 & 0 & 0 \\
\hline Ireland & 2001 and 2003 & 2 & 1 & 1 & 1 & 0 & 0 \\
\hline Finland & 2000 and 2004 & 3 & 1 & 0.8 & 1 & 0 & 0 \\
\hline
\end{tabular}

individual involved in financing entrepreneurial projects in the last 3 years and we use as an indication of wealth. Head of household income is available from GEM data categorised into low, middle, and high, based on percentiles of distribution, and we take the lowest income category as omitted benchmark. Taken jointly, we use all the individual control variables that have full coverage in GEM for our period of interest that is from 1999.

\subsubsection{Country level: macroeconomic and institutional environment}

We use two controls at the country level to account for financial dimensions of the country environment. First, we wish to control for availability of credit, and therefore, we include the size of domestic credit to the private sector as a percentage of GDP (private sector credit) $G D P$ ) to control for the level of financial development and in particular of banking sector development (e.g. Djankov et al. 2007). These data come from the World Bank World Development Indicators and are lagged by 1 year to alleviate possible endogeneity. Second, we include the minimum capital requirements for an entrepreneur to form a limited liability company, as these affect the type of organisational form entrepreneurs will choose and also the debt strategies of the start-ups. Armour and Cumming (2008) find that they negatively affect self-employment levels in Europe. Likewise, as the capital requirements represent an additional entry cost for limited liability ventures, previous research suggests that they may dampen incorporation rates (Djankov et al. 2002; Klapper et al. 2006). The measure (in Euros) is taken from Armour and Cumming (2008). Again, we lag it by 1 year. Whilst in previous work, the level of economic development and the security of property rights have been found to be important explanatory variables for country-level entrepreneurship (e.g. Wennekers et al. 2005; Estrin et al. 2013), we are using data only from advanced economies which are relatively uniform in terms of higher-order institutions and level of GDP per capita. We therefore do not consider these controls to be necessary for this particular sample. See Table 2 below for descriptive statistics of our dependent and control variables. 
Table 2 Table of descriptive statistics

\begin{tabular}{|c|c|c|c|c|}
\hline Variable & Mean & Min & Max & SD \\
\hline Start-up & 0.03 & 0 & 1 & 0.16 \\
\hline High asp 5 & 0.01 & 0 & 1 & 0.12 \\
\hline High asp 10 & 0.01 & 0 & 1 & 0.10 \\
\hline High asp 20 & 0.01 & 0 & 1 & 0.08 \\
\hline Female & 0.53 & 0 & 1 & 0.50 \\
\hline Age & 40.99 & 14 & 65 & 13.44 \\
\hline Age squared & 1861.15 & 196 & 4225 & 1110.09 \\
\hline Secondary education & 0.34 & 0 & 1 & 0.47 \\
\hline Higher education & 0.36 & 0 & 1 & 0.48 \\
\hline Full time employment & 0.59 & 0 & 1 & 0.49 \\
\hline Part-time employment & 0.09 & 0 & 1 & 0.29 \\
\hline Retired or disabled & 0.06 & 0 & 1 & 0.24 \\
\hline Homemaker & 0.06 & 0 & 1 & 0.24 \\
\hline Student & 0.04 & 0 & 1 & 0.20 \\
\hline Not working, other & 0.13 & 0 & 1 & 0.34 \\
\hline $\begin{array}{l}\text { Occupational status not } \\
\text { given }\end{array}$ & 0.02 & 0 & 1 & 0.16 \\
\hline Business angel last 3 years & 0.02 & 0 & 1 & 0.16 \\
\hline $\begin{array}{l}\text { Head of household: } \\
\text { middle income }\end{array}$ & 0.34 & 0 & 1 & 0.47 \\
\hline $\begin{array}{l}\text { Head of household: high } \\
\text { income }\end{array}$ & 0.25 & 0 & 1 & 0.43 \\
\hline Private sector credit/GDP & 118.36 & 34.87 & 191.20 & 31.75 \\
\hline $\begin{array}{l}\text { Minimum capital } \\
\text { requirements }\end{array}$ & 8.22 & 0 & 35 & 9.25 \\
\hline
\end{tabular}

\subsection{Model specification}

Due to the hierarchical nature of the data, the regressions are estimated using multilevel random coefficient logistic regression: individuals (level 1) are clustered in country-year samples (level 2). This means that an individual in the same country-year cluster has more similar characteristics to other individuals within the same cluster than to individuals in a different one. This implies lack of independence in the error term. If we were to use traditional regression techniques, then the standard errors would likely be biased, which could lead us to drawing incorrect conclusions from the models (Bliese 2002). The issue of dependency between observations in the same country-year cluster can be corrected by using country-year fixed effects and clustered standard errors. However, this would prevent the inclusion of level 2 variables such as corporate bankruptcy law-the focus of this study - as they vary very little over time (Snijders and Bosker 2012). Moreover, our questions are multilevel: we are interested in the relationship of variables at different levels: the influence of bankruptcy law (a country level variable) on an individual's likelihood of being a high-aspiration nascent entrepreneur (an individual level variable). Thus we use a multilevel model.

We use logistic regression as our dependent variable is dichotomous. ${ }^{5}$ Logistic regression estimates the probability that an individual will be a high-aspiration nascent entrepreneur. Estimation by logit is our preferred choice because we face a small proportion of observations in high-aspiration category compared to the rest of the working age population and it can be proved analytically that logit coefficients are not affected by such a skewed distribution (e.g. Maddala 2001). The models are estimated on the sample of 307,136 observations within 74 country-year clusters, based on the availability of all variables.

First, we estimate the between-country-year variance in the dependent variable (high-aspiration entrepreneurship) with no independent variables or controls (step 1). Second, we estimate a baseline equation by adding individual level controls and country-year level controls to the model (step 2). This results in our baseline model which is represented by combining Eqs. 1 and 2 below. Equation 1 represents the relationship between individual level variables and entrepreneurship. In these equations, $\pi_{i j}$ represents the probability of an individual $i$ starting a business in country-year j, $\Gamma$ represents a vector of individual level coefficients and $e_{i j}$ represents the individual-level error term. Note the subscript $j$ in the coefficient of $\beta_{0 j}$ in Eq. 1. This indicates that the intercept is treated as random coefficient and is allowed to vary across country-years, i.e. level 2 variables are related to high aspiration entrepreneurship. Hence, the need to specify Eq. 2 which indicates that the intercept is a function of vector of $p$ macrocontrols, $Z_{0 p}$, and a country-year level error term $U_{0 j}$. Third, we include the bankruptcy law variables to further explain how high aspiration entrepreneurship is related to level 2 factors (step 3). The estimated models presented in Table 3 are represented by combining Eqs. 1 and 3. Equation 3 indicates that the model's intercept $\beta_{0 j}$ is influenced by $\gamma_{01}$, which represents the

\footnotetext{
$\overline{{ }^{5} \text { We considered }}$ using multinomial logit, but the independence of irrelevant alternatives (IIA) assumption is clearly violated as the choice of being a low-growth nascent entrepreneur is much more similar to that of being a high-growth nascent entrepreneur than to not being an entrepreneur at all.
} 
effect of bankruptcy codes on high aspiration entrepreneurship.

$$
\begin{aligned}
\log \left(\frac{\pi_{i j}}{1-\pi_{i j}}\right)= & \beta_{0 j}+\Gamma(\text { individual level controls })_{i j} \\
& +e_{i j}
\end{aligned}
$$

$\beta_{0 j}=\gamma_{00}+Z_{0 p}$ (macro level controls $)+U_{0 j}$

$$
\begin{aligned}
\beta_{0 j}= & \gamma_{00}+Y_{01}(\text { bankruptcy code }) \\
& +Z_{0 p}(\text { macro level controls })+U_{0 j}
\end{aligned}
$$

\section{Results}

Results are reported in Table 3 below. All models in Table 3 include both personal and corporate bankruptcy indicators. We verified that entering them separately made little difference to the results. We present five separate models, four representing the four nested dependent variables (dummies) corresponding to the level of entrepreneurial growth aspirations defined by number of jobs to be created and the fifth, an alternative where we treat the different types of start-ups defined by level of aspirations as categories of one ordered variable, and estimate the random effects ordered logit model. Ordered logit models have been used in the literature (e.g. seminal paper by Reuer and Arino 2007), but the multilevel version we apply is little used.

Models 2-4 of Table 3 contain our core results for the dependent variable, high aspiration entrepreneurship, upon which we base our tests of Hypotheses 1 and 2. They report the results for step 3 discussed in the previous section; that is, including the three personal bankruptcy indicators, three corporate bankruptcy indicators and the control variables. Model 1 is the same except that it has a general measure of start-up; it is presented for the sake of transparency and plays no role in our hypotheses testing. It is provided for comparison, to show the same specifications for nascent entrepreneurship in general without reference to growth aspiration level (see discussion below). As a result, model 1 includes the same independent variables as models 2 to 4 . As already mentioned, model 5 use the same set of explanatory variables, except that this time, we combine all categories of entry into one ordered dependent variable. While the model is included as a robustness check, it is a less exact match of our hypotheses, as these relate to likelihood of high growth aspiration entry, yet random effects ordered logit coefficients also rely on differences in level of aspirations; an interesting but slightly different question than the one we hypothesised.

We report odds ratios (i.e. exponentiated coefficients) for ease of interpretation. The reported values correspond to the factors by which the odds of an individual becoming a nascent entrepreneur change for a unit change in the explanatory variable, holding all other variables constant (Long 1997). ${ }^{6}$ We tested the suitability of using a multilevel random intercept model on our data. As indicated above, we estimated first a null model with no coefficients (step 1) and carried out likelihood ratio tests which confirmed that a multilevel random intercept model is a more suitable model than a single level one $(p<0.001)$. The residual interclass correlation (IC) - the degree of unexplained variance at the country-year level-was $8.4 \%$ for start-ups in general (start-up) and $10.7 \%$ for high aspiration nascent entrepreneurs expecting to have more than 20 employees in 5 years' time (high asp 20). Interestingly, the higher unexplained variance for high aspiration nascent entrepreneurs indicates that country-year characteristics are more important for them than for nascent entrepreneurs in general. We then included all the individual and macro level controls; as a result, $4.9 \%$ of country-year variance was left unexplained for start-up and $9.3 \%$ for high asp 20. Finally, including both personal and corporate bankruptcy law makes a difference: it reduces the intra-class correlation to $1.6 \%$ for start-up and $2.2 \%$ for high asp 20.

With respect to personal bankruptcy law, we find very strong support for Hypotheses $1 \mathrm{a}$ and $\mathrm{b}$. That is, the elements we highlighted, lack of a fresh start with restrictions on rights of debtors and lack of protection of their personal assets, are associated with a lower likelihood of being engaged in a start-up and of high aspirations entrepreneurship in particular. The other component of the personal bankruptcy law, difficulty in reaching a compromise with creditors, has no effect on

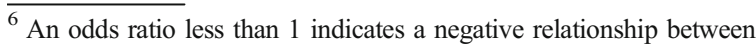
the independent and dependent variables and an odds ratio greater than 1 indicates a positive relationship.
} 
Table 3 Estimation results - random intercept logistic regression

\begin{tabular}{|c|c|c|c|c|c|}
\hline & $\begin{array}{l}\text { Model } 1 \\
\text { Start-up: } \\
\text { Low asp. }\end{array}$ & $\begin{array}{l}\text { Model } 2 \\
\text { High asp } \\
5+\text { jobs }\end{array}$ & $\begin{array}{l}\text { Model } 3 \\
\text { High asp } \\
10+\text { jobs }\end{array}$ & $\begin{array}{l}\text { Model } 4 \\
\text { High asp } \\
20+\end{array}$ & $\begin{array}{l}\text { Model } 5 \\
\text { Ordered } \\
\text { model }\end{array}$ \\
\hline \multicolumn{6}{|l|}{ Elements of personal bankruptcy codes } \\
\hline Fresh start & $\begin{array}{l}0.822 * * * \\
(0.036)\end{array}$ & $\begin{array}{l}0.825^{* * * *} \\
(0.037)\end{array}$ & $\begin{array}{l}0.834 * * * \\
(0.041)\end{array}$ & $\begin{array}{l}0.804 * * * \\
(0.053)\end{array}$ & $\begin{array}{l}0.822 * * * \\
(0.035)\end{array}$ \\
\hline Exemptions of personal assets & $\begin{array}{l}0.544 * * * \\
(0.037)\end{array}$ & $\begin{array}{l}0.527 * * * \\
(0.036)\end{array}$ & $\begin{array}{l}0.517 * * * \\
(0.038)\end{array}$ & $\begin{array}{l}0.472 * * * \\
(0.046)\end{array}$ & $\begin{array}{l}0.543 * * * \\
(0.037)\end{array}$ \\
\hline Compromise with creditors difficult & $\begin{array}{l}1.076 \\
(0.124)\end{array}$ & $\begin{array}{l}1.016 \\
(0.121)\end{array}$ & $\begin{array}{l}0.928 \\
(0.121)\end{array}$ & $\begin{array}{l}0.974 \\
(0.169)\end{array}$ & $\begin{array}{l}1.073 \\
(0.123)\end{array}$ \\
\hline \multicolumn{6}{|l|}{ Elements of corporate bankruptcy codes } \\
\hline Secured creditors first & $\begin{array}{l}0.573 * * * \\
(0.078)\end{array}$ & $\begin{array}{l}0.586 * * * \\
(0.079)\end{array}$ & $\begin{array}{l}0.686^{* * *} \\
(0.099)\end{array}$ & $\begin{array}{l}0.617 * \\
(0.121)\end{array}$ & $\begin{array}{l}0.574 * * * \\
(0.078)\end{array}$ \\
\hline Restrictions on reorganisation & $\begin{array}{l}0.979 \\
(0.101)\end{array}$ & $\begin{array}{l}1.250^{*} \\
(0.124)\end{array}$ & $\begin{array}{l}1.499 * * * \\
(0.158)\end{array}$ & $\begin{array}{l}1.738^{* * * *} \\
(0.245)\end{array}$ & $\begin{array}{l}0.983 \\
(0.101)\end{array}$ \\
\hline No automatic stay and management goes & $\begin{array}{l}1.001 \\
(0.051)\end{array}$ & $\begin{array}{l}0.921 \\
(0.046)\end{array}$ & $\begin{array}{l}0.864 * * \\
(0.046)\end{array}$ & $\begin{array}{l}0.856^{*} \\
(0.061)\end{array}$ & $\begin{array}{l}1.001 \\
(0.050)\end{array}$ \\
\hline \multicolumn{6}{|l|}{ Individual-level control variables } \\
\hline Female & $\begin{array}{l}0.480 * * * \\
(0.013)\end{array}$ & $\begin{array}{l}0.422^{* * * *} \\
(0.016)\end{array}$ & $\begin{array}{l}0.429 * * * \\
(0.020)\end{array}$ & $\begin{array}{l}0.474 * * * \\
(0.026)\end{array}$ & $\begin{array}{l}0.479 * * * \\
(0.013)\end{array}$ \\
\hline Age & $\begin{array}{l}1.093 * * * \\
(0.007)\end{array}$ & $\begin{array}{l}1.062^{* * * *} \\
(0.009)\end{array}$ & $\begin{array}{l}1.071 * * * \\
(0.011)\end{array}$ & $\begin{array}{l}1.066^{* * * *} \\
(0.013)\end{array}$ & $\begin{array}{l}1.092 * * * \\
(0.007)\end{array}$ \\
\hline Age squared & $\begin{array}{l}0.999 * * * \\
(0.000)\end{array}$ & $\begin{array}{l}0.999 * * * \\
(0.000)\end{array}$ & $\begin{array}{l}0.999 * * * \\
(0.000)\end{array}$ & $\begin{array}{l}0.999 * * * \\
(0.000)\end{array}$ & $\begin{array}{l}0.999 * * * \\
(0.000)\end{array}$ \\
\hline Secondary education $^{\mathrm{a}}$ & $\begin{array}{l}0.862 * * * \\
(0.014)\end{array}$ & $\begin{array}{l}0.872^{* * * *} \\
(0.019)\end{array}$ & $\begin{array}{l}0.856^{* * * *} \\
(0.022)\end{array}$ & $\begin{array}{l}0.869 * * * \\
(0.027)\end{array}$ & $\begin{array}{l}0.863 * * * \\
(0.014)\end{array}$ \\
\hline Higher education & $\begin{array}{l}1.159 * * * \\
(0.018)\end{array}$ & $\begin{array}{l}1.147^{* * * *} \\
(0.025)\end{array}$ & $\begin{array}{l}1.169 * * * \\
(0.030)\end{array}$ & $\begin{array}{l}1.151 * * * \\
(0.036)\end{array}$ & $\begin{array}{l}1.159 * * * \\
(0.018)\end{array}$ \\
\hline Business angel last 3 years & $\begin{array}{l}1.402 * * * \\
(0.029)\end{array}$ & $\begin{array}{l}1.387 * * * \\
(0.034)\end{array}$ & $\begin{array}{l}1.386^{* * * *} \\
(0.037)\end{array}$ & $\begin{array}{l}1.362 * * * \\
(0.042)\end{array}$ & $\begin{array}{l}1.404 * * * \\
(0.029)\end{array}$ \\
\hline Part-time employment ${ }^{\mathrm{b}}$ & $\begin{array}{l}1.300 * * * \\
(0.060)\end{array}$ & $\begin{array}{l}1.116 \\
(0.075)\end{array}$ & $\begin{array}{l}1.146 \\
(0.091)\end{array}$ & $\begin{array}{l}1.151 \\
(0.111)\end{array}$ & $\begin{array}{l}1.295 * * * \\
(0.060)\end{array}$ \\
\hline Retired or disabled & $\begin{array}{l}0.614 * * * \\
(0.051)\end{array}$ & $\begin{array}{l}0.544 * * * \\
(0.065)\end{array}$ & $\begin{array}{l}0.567 * * * \\
(0.081)\end{array}$ & $\begin{array}{l}0.537 * * * \\
(0.093)\end{array}$ & $\begin{array}{l}0.614 * * * \\
(0.051)\end{array}$ \\
\hline Homemaker & $\begin{array}{l}0.539 * * * \\
(0.053)\end{array}$ & $\begin{array}{l}0.431^{* * *} \\
(0.070)\end{array}$ & $\begin{array}{l}0.490 \text { *** } \\
(0.091)\end{array}$ & $\begin{array}{l}0.458 * * * \\
(0.104)\end{array}$ & $\begin{array}{l}0.539 * * * \\
(0.053)\end{array}$ \\
\hline Student & $\begin{array}{l}0.438 * * * \\
(0.049)\end{array}$ & $\begin{array}{l}0.505^{* * *} \\
(0.073)\end{array}$ & $\begin{array}{l}0.588 * * \\
(0.098)\end{array}$ & $\begin{array}{l}0.576^{* *} \\
(0.119)\end{array}$ & $\begin{array}{l}0.439 * * * \\
(0.049)\end{array}$ \\
\hline Not working, other & $\begin{array}{l}0.934 \\
(0.042)\end{array}$ & $\begin{array}{l}0.846^{* *} \\
(0.052)\end{array}$ & $\begin{array}{l}0.846 * \\
(0.061)\end{array}$ & $\begin{array}{l}0.824 * \\
(0.071)\end{array}$ & $\begin{array}{l}0.932 \\
(0.042)\end{array}$ \\
\hline Occupational status not given & $\begin{array}{l}0.973 \\
(0.128)\end{array}$ & $\begin{array}{l}1.010 \\
(0.168)\end{array}$ & $\begin{array}{l}0.877 \\
(0.182)\end{array}$ & $\begin{array}{l}1.148 \\
(0.258)\end{array}$ & $\begin{array}{l}0.974 \\
(0.129)\end{array}$ \\
\hline Middle income ${ }^{\mathrm{c}}$ & $\begin{array}{l}1.101 * * \\
(0.036)\end{array}$ & $\begin{array}{l}1.119 * \\
(0.052)\end{array}$ & $\begin{array}{l}1.108 \\
(0.062)\end{array}$ & $\begin{array}{l}1.093 \\
(0.073)\end{array}$ & $\begin{array}{l}1.102 * * \\
(0.036)\end{array}$ \\
\hline High income & $\begin{array}{l}1.255^{* * *} \\
(0.043)\end{array}$ & $\begin{array}{l}1.459 * * * \\
(0.069)\end{array}$ & $\begin{array}{l}1.476^{* * *} \\
(0.083)\end{array}$ & $\begin{array}{l}1.379 * * * \\
(0.093)\end{array}$ & $\begin{array}{l}1.261 * * * \\
(0.043)\end{array}$ \\
\hline Country-level control variables & & & & & \\
\hline Minimum capital requirements & $\begin{array}{l}0.985^{* *} \\
(0.006)\end{array}$ & $\begin{array}{l}1.000 \\
(0.006)\end{array}$ & $\begin{array}{l}1.010 \\
(0.006)\end{array}$ & $\begin{array}{l}1.016 \\
(0.008)\end{array}$ & $\begin{array}{l}0.986^{*} \\
(0.006)\end{array}$ \\
\hline
\end{tabular}


Table 3 (continued)

\begin{tabular}{|c|c|c|c|c|c|}
\hline & $\begin{array}{l}\text { Model } 1 \\
\text { Start-up: } \\
\text { Low asp. }\end{array}$ & $\begin{array}{l}\text { Model } 2 \\
\text { High asp } \\
5+\text { jobs }\end{array}$ & $\begin{array}{l}\text { Model } 3 \\
\text { High asp } \\
10+\text { jobs }\end{array}$ & $\begin{array}{l}\text { Model } 4 \\
\text { High asp } \\
20+\end{array}$ & $\begin{array}{l}\text { Model } 5 \\
\text { Ordered } \\
\text { model }\end{array}$ \\
\hline Private sector credit/GDP & $\begin{array}{l}1.001 \\
(0.001)\end{array}$ & $\begin{array}{l}1.001 \\
(0.002)\end{array}$ & $\begin{array}{l}1.002 \\
(0.002)\end{array}$ & $\begin{array}{l}1.001 \\
(0.002)\end{array}$ & $\begin{array}{l}1.001 \\
(0.001)\end{array}$ \\
\hline Constant & $\begin{array}{l}0.045^{* * * *} \\
(0.015)\end{array}$ & $\begin{array}{l}0.037^{* * *} \\
(0.014)\end{array}$ & $\begin{array}{l}0.019 * * * \\
(0.008)\end{array}$ & $\begin{array}{l}0.012 * * * \\
(0.006)\end{array}$ & \\
\hline Cutpoint 1 (start-up) & & & & & $\begin{array}{l}21.788 * * * \\
(7.223)\end{array}$ \\
\hline Cutpoint 2 (start-up, aspirations: 5 jobs) & & & & & $\begin{array}{l}43.030 * * * \\
(14.273)\end{array}$ \\
\hline Cutpoint 3 (start-up, aspirations: 10 jobs) & & & & & $\begin{array}{l}61.617^{* * * *} \\
(20.449)\end{array}$ \\
\hline Cutpoint 4 (start-up, aspirations: 20 jobs) & & & & & $\begin{array}{l}90.999 * * * \\
(30.226)\end{array}$ \\
\hline Log of random effect's S.D. & $\begin{array}{l}-2.96^{* * *} \\
(0.014)\end{array}$ & $\begin{array}{l}-3.27 * * * \\
(0.014)\end{array}$ & $\begin{array}{l}-3.32 * * * \\
(0.015)\end{array}$ & $\begin{array}{l}-2.60 * * * \\
(0.026)\end{array}$ & \\
\hline Log likelihood & $-28,684$ & $-17,006$ & $-12,774$ & -9342 & $-37,013$ \\
\hline Wald Chi squared & 2653 & 1794 & 1366 & 839.8 & 2667 \\
\hline Estimated residual S.D. of random effect & 0.229 & 0.194 & 0.189 & 0.272 & 0.227 \\
\hline Estimated intra-country residual correlation & 0.0157 & 0.0113 & 0.0107 & 0.0219 & \\
\hline
\end{tabular}

*** $p<0.001 ; * * p<0.01 ; * p<0.05$; Exponentiated coefficients; exponentiated standard errors in parentheses; Observations: 255,275; Country year groups: 64; Year dummies included in all regressions but not reported

${ }^{\text {a }}$ The benchmark omitted category for education is primary education or less.

${ }^{b}$ The benchmark omitted category for work status is full time employment.

${ }^{\mathrm{c}}$ The benchmark omitted category for head of household income is low (being in the lowest $1 / 3$ of income distribution)

entrepreneurial aspirations, consistent with prospect theory.

Next, considering the direct effects of corporate bankruptcy law on high-aspiration entrepreneurship, presented in models 2 to 4 in Table 3, we find that our scale that combines no automatic stay and management goes is significant for high-aspiration entrepreneurship when defined by either 10 jobs or more, or 20 jobs or more. It is not significant for the level of aspirations defined by five jobs and for general start-up model (models 1 to 4 ). While the results are slightly weaker than for personal bankruptcy, the pattern is consistent with Hypothesis 2.

We also find restrictions on reorganisation to be significant in all the high aspiration entrepreneurship models 1-4. While prospect theory suggests these should be less relevant to the entrepreneur at time of making entry decision, they should be highly relevant to creditors. If so, this would enhance the supply of credit and provide support especially to higher aspirations entrepreneurs, which is what we find.
Finally, for secured creditors first, the coefficient is significant in all reported models where we have personal and corporate indicators jointly. However, unlike previous cases, this significance is likely to be caused by the pattern of multicollinearity between personal and corporate bankruptcy indicators, because in models where we entered either the set of personal bankruptcy indicators or the set of corporate bankruptcy indicators separately, the indicators were no longer significant (not reported). Therefore, we have less faith in this result.

There is an interesting difference in patterns of results for personal versus corporate bankruptcy variables. For personal bankruptcy indicators, we see similar level of significance for our general start-up dependent variable and for our high-aspirations entry dependent variables. However, in contrast, for corporate bankruptcy, the no automatic stay and management goes scale displays a pattern in which the results are not significant for start-up and for start-ups with 5 or more jobs expected, but clearly significant for the most ambitious forms of 
entrepreneurship. That makes sense: it is typically only for larger-size projects that the entrepreneurs consider incorporation, and therefore the features of corporate bankruptcy law become relevant.

The models in Table 3 are also consistent with the literature regarding the control variables. At the individual level, male, educated and middle-aged individuals are more likely to be high-aspiration entrepreneurs. Wealthier individuals (proxied by whether they have been a business angel in the last 3 years) and those with high income are more likely to be entrepreneurs across all categories of aspirations. Additionally, employed individuals (our base category) are more likely to be entrepreneurs than retired, disabled, students, homemakers and individuals who are not working. The effect size increases as the scale of aspiration increases.

At the country level, the size of the domestic credit market to GDP is not significant. It becomes statistically significant only when personal bankruptcy laws are not included in the models (not reported). The elements of bankruptcy law exhibit moderate correlations with the size of the credit market (the highest one is $-32 \%$ with our composite measure of no discharge and restrictions on debtors); these seem to cause some multicollinearity. At the same time, (unexpected) negative signs of those correlations suggest that stringency of the personal bankruptcy law has no positive impact on the overall supply of credit, again consistent with our focus on entrepreneurs and not on creditors.

Higher minimal capital requirements have an ambiguous impact. The results indicate a strong negative impact on our general measure of start-up, but not on more ambitious forms of entrepreneurship. This is intuitive: those entrepreneurs who have more ambitious plans need more capital and therefore are not affected by the threshold levels of regulations. This is an interesting finding as it suggests that although minimum capital requirements may discourage entrepreneurial entry in general, they do not discourage the most ambitious entrepreneurs.

\section{Discussion}

Previous research has highlighted that the impact of the bankruptcy code on entrepreneurship is composed of two effects. On the one hand, rules giving creditors more power may increase the likelihood of an individual becoming an entrepreneur. This is an indirect effect caused by an increase in the supply of finance resulting from a more creditor friendly environment (La Porta et al. 1998; Djankov et al. 2007) and of particular importance when entrepreneurs are financially constrained. On the other hand, some elements of the code act to reduce the likelihood of an individual choosing to become a high-growth entrepreneur, because of their effects on the expected outcomes following financial distress (Armour and Cumming 2008; Lee et al. 2007, 2011; Peng et al. 2010). In previous research, there has been ambiguity as to which of the two effects will dominate (Lee et al. 2011; Lee and Yamakawa 2012). We suggest that prospect theory offers a theoretical explanation when focusing on potential entrepreneurs, who are characterised by loss aversion when comparing the potential gains and losses to their wealth and control at the point of venture creation. The effects that matter most for entrepreneurs are those that relate to their assets and decision rights at the time of entry. In this context, prospect theory led us to generate unambiguous hypotheses about the negative effects on highaspiration entrepreneurship of bankruptcy law when: there is no fresh start with no discharge after personal bankruptcy and restrictions are imposed on the debtor, there are fewer exemptions of personal assets from the creditors' claims on the debtor in personal bankruptcy, there no automatic stay on assets and where managers are removed during corporate bankruptcy proceedings.

Our empirical work has established evidence supporting these hypotheses. We find that those elements of personal and corporate bankruptcy law that have a statistically significant and negative impact on entry into high aspiration entrepreneurship are those elements that leave debtors with less protection for assets and decision rights during and after bankruptcy. In the case of rights, these relate not only to control over the new venture but to other economic and civic rights that the (potential) entrepreneur has at the time of startup decision. For the elements of the bankruptcy code listed above, the direct disincentive effect on high aspiration entrepreneurs seems to be more than compensating for any indirect effects via the supply of finance.

In contrast, the results related to the conditions on reaching a compromise between the creditors and the debtors are ambiguous as here creditors' incentives counterbalance the effect of a milder bankruptcy regime on entrepreneurs. Furthermore, it seems that enhancing creditors' rights in reorganisation so that so that their consent and rights to dividends play an essential role in 
reorganisation decisions, results in higher prevalence of high growth aspiration projects (restrictions on reorganisation in corporate bankruptcy law), presumably via the indirect effects enhancing the supply of credit. Prospect theory offers a possible explanation as the removal of the ability for the entrepreneur to unilaterally decide whether to enter reorganisation or liquidation bankruptcy does not relate to potential losses for entrepreneur as evaluated with respect to his/her position at the time of start-up. Thus, the disincentive effects of a more penal bankruptcy system that are less directly associated with the issue of managerial control, are more than offset by the impact of the increase in the supply of finance resulting from a more creditor friendly financial environment. As a result, this study adds to the literature on bankruptcy law and entrepreneurship.

It is also the first to analyse the effects of both personal and corporate bankruptcy law at the same time, and to distinguish between different aspirations levels of entrepreneurs. This allows our findings to contribute to the debate on the relevance of corporate bankruptcy law to entrepreneurship (Cumming 2012; Lee and Yamakawa 2012) by showing that both personal bankruptcy law and corporate bankruptcy law influence high impact entrepreneurship. Interestingly, when we pitch the elements of corporate bankruptcy law against the elements of personal bankruptcy law in model 4 for highest aspiration entrepreneurs, the clear winner is the protection of personal assets. Likewise, comparing between models 1 to 4 , we see how the negative impact of no or few exemptions on personal assets steadily increases as we move to more ambitious forms of entrepreneurship. Even a small risk of losing their home seems critical for high aspiration entrepreneurs. It is important to draw attention to these differences as these results add to the growing body of evidence that shows that the effects of institutions may vary depending on the level of aspirations and highlights the importance of distinguishing between more and less ambitious forms of entrepreneurship (Levie and Autio 2011; Estrin et al. 2013).

\section{Conclusions}

Taken together, all our results support the proposition that was our departure point: the ambiguity about the direction of the effect of bankruptcy law on entry into high-aspiration entrepreneurship can be explained through the use of prospect theory. Prospect theory explains why certain elements of bankruptcy law are more salient to entrepreneurs than others. Thus, rather than seeing all elements of bankruptcy law that give power to debtors as entrepreneur friendly, we conclude that the optimum design of bankruptcy law should take into account that creditors care about different elements of the bankruptcy process than do entrepreneurs.

It is the application of prospect theory that helped us to understand why. We therefore make a case for its being an important tool that can help us to explain patterns in entrepreneurship. The impact of bankruptcy regimes is just one element of risks faced by the entrepreneur, and accordingly prospect theory may have much wider implications for entrepreneurship research.

There are a number of limitations of our study. Many of these relate to the data which we have at our disposal. While the indicators of creditor rights introduced by La Porta et al. (1998) represent a major advance in terms of cross country measurement of the harshness of the bankruptcy code, our results also support the arguments of Claessens and Klapper (2005) that these measures do not adequately capture the complexities of corporate bankruptcy law. Moreover, there is limited variation of the indicators over the time period for which GEM data matching the creditor rights indices are available. Similar limitations relate to personal bankruptcy codes. Future research would doubtlessly benefit from the development of more sophisticated and finely grained measures of bankruptcy codes, and from analysis over a longer period of time in order to establish the hypotheses more firmly and to address more deeply potential issues of causality and endogeneity.

Another consideration is that corporate or personal bankruptcy law is likely to have less impact on entrepreneurial behaviour in developing countries where the bulk of new firm entry is in the informal sector and is not registered. However, focusing on the most developed countries makes us confident that the problem is less serious for our sample.

Finally, we focus exclusively on formal institutions and do not control for culture. Unlike bankruptcy regulations that do change in some countries over a period of time, we consider culture to be a slow-moving dimension. Therefore, the small number of countries we have in our sample becomes a serious problem in estimations, if we include culture as it is the cross-section not the time dimension that matters. At the same time, some aspects of culture, such as uncertainty avoidance (Wennekers et al. 2007; Li and Zahra 2012; Hayton 
and Cacciotti 2013) may be critical for high-aspiration entrepreneurship (see also Gartner and Liao 2012; De Clercq et al. 2014; Simmons et al. 2014). Individualism versus collectivism could be another relevant cultural control (Pinillos and Reyes 2011) as it may affect both entrepreneurial attitudes and concepts of responsibility inherent in bankruptcy law. ${ }^{7}$ With more data, one could even think about two equations models, where culture affects the design of bankruptcy law, which in turn affects entrepreneurs' choice. Yet, another fruitful path to account for the impact of culture on bankruptcy regulations is to move beyond quantitative studies and to adopt historical methods, an approach that is successfully applied by Martin (2005).

Finally, our analysis has some important policy implications. The results suggest that financial institutions, in particular the harshness of the bankruptcy code, play a complex role in encouraging entrepreneurship. Thus, policy makers may be able to design bankruptcy law in a way that simultaneously favours creditors without excessively demotivating potential entrepreneurs. The evidence indicates that some elements of a harsh bankruptcy regime do deter some individuals from becoming entrepreneurs and in particular high aspiration entrepreneurs. Whilst corporate bankruptcy law does not impact on low-aspiration entrepreneurs, policy makers who wish to encourage high-aspiration entrepreneurs should pay close attention to it. In corporate bankruptcy law, limitations in the bankruptcy proceedings on the entrepreneurs' control over the firm, such as an automatic stay on secured assets and mandatory removal of the management, are associated with lower likelihood of individuals entering high-aspiration entrepreneurship which suggests that such provisions should be avoided. However, some elements of creditor-friendly corporate bankruptcy law such as restrictions on reorganisation have a positive relationship to high-growth aspiration entrepreneurship. With this element of corporate bankruptcy law, it appears that the discouraging effect of creditor-friendly rules that disempower debtors is offset by a positive effect via the supply of finance. This suggests that the limitation of the supply of credit remains one of the constraints on high aspiration entrepreneurship, and it is therefore likely to affect economic growth, innovations and jobs. Thus whilst many debtorfriendly aspects of bankruptcy law do encourage high

\footnotetext{
${ }^{7}$ Here, we are indebted to the anonymous referee for discussion and suggestions.
}

aspiration entrepreneurship, this conclusion cannot be applied to all elements of bankruptcy law-in some cases protecting creditors rather than debtors is a better policy.

Acknowledgments We are indebted to our anonymous reviewers, Moren Lévesque, Philipp Koellinger, Svetlana Makarova, Mirjam Van Praag, Mike Wright for comments and criticism. Any remaining errors are our own.

Open Access This article is distributed under the terms of the Creative Commons Attribution 4.0 International License (http:// creativecommons.org/licenses/by/4.0/), which permits unrestricted use, distribution, and reproduction in any medium, provided you give appropriate credit to the original author(s) and the source, provide a link to the Creative Commons license, and indicate if changes were made.

\section{References}

Aidis, R., Estrin, E., \& Mickiewicz, T. (2012). Size matters: entrepreneurial entry and government. Small Business Economics, 39(1), 119-139.

Armour, J. (2001). The law \& economics of corporate insolvency: a review. In ESRC Centre for business research working paper 62. Cambridge: University of Cambridge.

Armour, J., \& Cumming, D. (2008). Bankruptcy law and entrepreneurship. American Law and Economics Review, 10(2), 303-350.

Arrow, K. (1971). Essays in the theory of risk bearing. Chicago: Markham.

Audretsch, D. (1991). New-firm survival and the technological regime. The Review of Economics and Statistics., 73(3), 441-450.

Barberis, N., \& Thaler, R. (2003). Survey of behavioral finance, handbook of the economics of finance. New York: Elsevier.

Baumol, W. (1990). Entrepreneurship: productive, unproductive and destructive. Journal of Political Economy, 98(5), 893-921.

Berkowitz, J., \& White, M. J. (2004). Bankruptcy and small firms' access to credit. RAND Journal of Economics, 35(Spring), 69-84.

Bliese, P. D. (2002). Multilevel random coefficient modelling in organizational research. In F. Drasgow \& N. Schmitt (Eds.), Measuring and analyzing behavior in organizations: advances in measurement and data analysis. San Francisco: Jossey-Bass.

Bosma, N., \& Levie, J. (2009). Global Entrepreneurship Monitor 2009 executive report: Global Entrepreneurship Research Association.

Bowen, H. P., \& De Clercq, D. (2008). Institutional context and the allocation of entrepreneurial effort. Journal of International Business Studies, 39, 747-767.

Brouwer, M. (2006). Reorganization in US and European bankruptcy law. European Journal of Law and Economics, 22(1), 5-20.

Buchanan, J. M. (1979). Cost and choice: an inquiry in economic theory. Chicago: University of Chicago Press. 
Busenitz, L. W., Gómez, C., \& Spencer, J. W. (2000). Country institutional profiles: unlocking entrepreneurial phenomenon. Academy of Management Journal, 43(5), 994-1003.

Cirmizi, E., Klapper, L., \& Uttamchandani, M. (2011). The challenges of bankruptcy reform. The World Bank Research Observer, 27(2), 185-203.

Claessens, S., \& Klapper, L. F. (2005). Bankruptcy around the world: explanations of its relative use. American Law and Economics Review, 7(1), 253-283.

Cumming, D. J. (2012). Measuring the effect of bankruptcy laws on entrepreneurship across countries. The Journal of Entrepreneurial Finance, 16(1), 80-86.

Dally, C. (1994). Bankruptcy in strategic studies: past and promise. Journal of Management, 20(2), 263-295.

De Clercq, D., Lim, D. S., \& Oh, C. H. (2014). Hierarchy and conservatism in the contributions of resources to entrepreneurial activity. Small Business Economics, 42(3), 507-522.

Dew, N., Sarasathy, S., Read, S., \& Wiltbank, R. (2009). Affordable loss: behavioral economic aspects of the plunge decision. Strategic Entrepreneurship Journal, 3(2), 105-126.

Djankov, S., La Porta, R., Lopez-de-Silanes, F., \& Shleifer, A. (2002). The regulation of entry. The Quarterly Journal of Economics, 117(1), 1-37.

Djankov, S., McLiesh, C., \& Shleifer, A. (2007). Private credit in 129 countries. Journal of Financial Economics, 84(2), 299329.

Djankov, S., Hart, O., McLiesh, C., \& Shleifer, A. (2008). Debt enforcement around the world. Journal of Political Economy, 116(6), 1105-1149.

Efrat, R. (2002). Global trends in personal bankruptcy. American Bankruptcy Law Journal, 76(1), 81-110.

Estrin, S., \& Mickiewicz, T. (2011). Institutions and female entrepreneurship. Small Business Economics, 37(4), 397-415.

Estrin, S., Korosteleva, J., \& Mickiewicz, T. (2013). Which institutions encourage entrepreneurial growth aspirations? Journal of Business Venturing, 28(4), 564-580.

Estrin, S., Mickiewicz, T., \& Stephan, U. (2016). Human capital in social and commercial entrepreneurship. Journal of Business Venturing, 31(4), 449-467.

Evans, D. S., \& Jovanovic, B. (1989). An estimated model of entrepreneurial choice under liquidity constraints. Journal of Political Economy, 97(4), 808-827.

Fan, W., \& White, M. J. (2003). Personal bankruptcy and the level of entrepreneurial activity. Journal of Law and Economics, 46(2), 543-567.

Foss, N., \& Klein, P. (2012). Organizing entrepreneurial judgment. Cambridge: Cambridge University Press.

Gartner, W., \& Liao, J. (2012). The effects of perceptions of risk, environmental uncertainty, and growth aspirations on new venture creation success. Small Business Economics, 39(3), 703-712.

Geroski, P. A. (1995). What do we know about entry? International Journal of Industrial Organization, 13(4), 421-440.

Gimeno, J., Folta, T., Cooper, A., \& Woo, C. (1997). Survival of the fittest? Human entrepreneurial capital and the persistence of firms. Administrative Science Quarterly, 42(4), 750-783.

Hart, O. (2000). Different approaches to bankruptcy. Harvard Institute of Economic research paper. Cambridge, MA: Harvard University.
Hayton, J. C., \& Cacciotti, G. (2013). Is there an entrepreneurial culture? A review of empirical research. Entrepreneurship \& Regional Development, 25(9-10), 708-731.

Headd, B. (2003). Redefining business success: distinguishing between closure and failure. Small Business Economics, 21(1), 51-61.

Henrekson, M., \& Johansson, D. (2010). Gazelles as job creators: a survey and interpretation of the evidence. Small Business Economics, 35(2), 227-244.

Henrekson, M., \& Sanandaji, T., (2014). Small business activity does not measure entrepreneurship, Proceedings of the National Academy of Sciences of the USA, http://www. pnas.org/content/early/2014/01/15/1307204111.abstract

Kahneman, D. (2011). Thinking, fast and slow. London: Penguin Books.

Kahneman, D., \& Tversky, A. (1979). Prospect theory: an analysis of decision under risk. Econometrica, 47(2), 263-291.

Klapper, L. F., Laeven, L., \& Rajan, R. (2006). Entry regulation as a barrier to entrepreneurship. Journal of Financial Economics, 86(3), 591-629.

Knight, F. H. (2009). Risk, uncertainty and profit. Kissimmee, FL: Signalman Publishing.

La Porta, R., Lopez-de-Silanes, F., Shleifer, A., \& Vishny, R. W. (1997). Legal determinants of external finance. Journal of Finance 52(July) 1131-1150.

La Porta, R., Lopez-de-Silanes, F., Shleifer, A., \& Vishny, R. W. (1998). Law and finance. Journal of Political Economy, 106(6), 1113-1155.

Lee, S.-H., \& Yamakawa, Y. (2012). Forgiving features for failed entrepreneurs vs. cost of financing in bankruptcies. Management International Review, 52(1), 49-79.

Lee, S.-H., Peng, M. W., \& Barney, J. B. (2007). Bankruptcy law \& entrepreneurship development: a real options perspective. Academy of Management Review, 32(1), 257-272.

Lee, S.-H., Yamakawa, Y., Peng, M. W., \& Barney, J. B. (2011). How do bankruptcy laws affect entrepreneurship development around the world? Journal of Business Venturing, 26(5), 505-520.

Levesque, M., \& Minniti, M. (2006). The effect of aging on entrepreneurial behaviour. Journal of Business Venturing, 21(2), 177-194.

Levie, J., \& Autio, E. (2011). Regulatory burden, rule of law and entry of strategic entrepreneurs: an international panel study. Journal of Management Studies, 48(6), 1392-1419.

Levie, J., \& Hart, M. (2010). Global Entrepreneurship Monitor. United Kingdom 2009 Monitoring Report. Strathclyde University and Aston Business School.

Levie, J., Autio, E., Acs, Z., \& Hart, M. (2014). Global entrepreneurship and institutions: an introduction. Small Business Economics, 42(3), 437-444.

Levine, R., \& Rubinstein, Y., (2013). Smart and illicit: who becomes an entrepreneur and does it pay? http://ssrn. com/abstract=2314667

Li, Y., \& Zahra, S. A. (2012). Formal institutions, culture, and venture capital activity: a cross-country analysis. Journal of Business Venturing, 27(1), 95-111.

Long, J. S. (1997). Regression models for categorical and limited dependent variables. Thousand Oaks: SAGE publications.

Maddala, G. S. (2001). Introduction to econometrics. Chichester: Willey. 
Martin, N. (2005). The role of history and culture in developing bankruptcy and insolvency systems: the perils of legal transplantation. Boston College International and Comparative Law Review, 28(2), 1-77.

Mata, J., \& Portugal, P. (1994). Life duration of new firms. Journal of Industrial Economics., 42(3), 227-245.

McGrath, R. G. (1999). Falling forwards: real option reasoning and entrepreneurial failure. Academy of Management Review, 24(1), 13-30.

McMullen, J., Bagby, D., \& Palich, L. (2008). Economic freedom and the motivation to engage in entrepreneurial action. Entrepreneurship Theory and Practice, 32(5), 875-895.

Parker, S. C. (2009). The economics of entrepreneurship. Cambridge: Cambridge University Press.

Peng, M. W., Yamakawa, Y., \& Lee, S. H. (2010). Bankruptcy laws and entrepreneur friendliness. Entrepreneurship Theory and Practice, 34(3), 517-530.

Pinillos, M. J., \& Reyes, L. (2011). Relationship between individualist-collectivist culture and entrepreneurial activity: evidence from global entrepreneurship monitor data. Small Business Economics, 37(1), 23-37.

Pochet, C. (2002). Institutional complementarities within corporate governance systems: a comparative study of bankruptcy rules. Journal of Management and Governance, 6(4), 343-381.

Posner, R. (2007). Economic analysis of law. New York: Aspen.

Prentice, D., Oditah, F., \& Segal, N. (2003). Administration: part II of the insolvency act 1986. In J. S. Ziegel (Ed.), Current developments in international and comparative corporate insolvency law (2nd ed.). Oxford: Clarendon Press.

Reuer, J. J., \& Arino, A. (2007). Strategic alliance contracts: dimensions and determinants of contractual complexity. Strategic Management Journal, 28(3), 313-330.

Reynolds, P. D. (2010). New firm creation: a global assessment of national, contextual, and individual factors. Foundations and Trends in Entrepreneurship, 6(5-6), 315-496.

Reynolds, P., Bosma, N., Autio, E., Hunt, S., De Bono, N., Servais, I., Lopez-Garcia, P., \& Chin, N. (2005). Global entrepreneurship monitor: data collection design and implementation 1998-2003. Small Business Economics, 24(3), 205-231.

Sarasvathy, S. (2001). Causation and effectuation: toward a theoretical shift from economic inevitability to entrepreneurial contingency. Academy of Management Review, 26(1), 243263.

Shleifer, A., \& Vishny, R. (1997). A survey of corporate governance. Journal of Finance, 52(2), 737-783.
Simmons, S. A., Wiklund, J., \& Levie, J. (2014). Stigma and business failure: implications for entrepreneurs' career choices. Small Business Economics, 42(3), 485-505.

Snijders, T. A. B., \& Bosker, R. J. (2012). Multilevel analysis: an introduction to basic and advanced multilevel modeling (2nd ed.). London: Sage.

Sobel, R. (2008). Testing baumol: institutional quality and the productivity of entrepreneurship. Journal of Business Venturing, 23(6), 641-655.

Stephan, U., Hart, M., Mickiewicz, T., \& Drews, C. C. (2015). Understanding motivations for entrepreneurship. BIS Research Paper No. 212.

Thaler, R. (1980). Toward a positive theory of consumer choice. Journal of Economic Behavior and Organization, 1(1), 39-60.

Troilo, M. (2011). Legal institutions and high-growth aspiration entrepreneurship. Economic Systems, 35(2), 158-175.

Tversky, A., \& Kahneman, D. (1992). Advances in prospect theory: cumulative representation of uncertainty. Journal of Risk and Uncertainty, 5, 297-323.

van Stel, A., Storey, D., \& Thurik, R. (2007). The effect of business regulations on nascent and young business entrepreneurship. Small Business Economics, 28(2-3), 171-186.

Vanacker, T., \& Manigart, S. (2010). Pecking order and debt capacity considerations for high growth companies seeking financing. Small Business Economics, 35(1), 53-69.

Wennberg, K., Wiklund, J., DeTienne, D. R., \& Cardon, M. S. (2010). Reconceptualizing entrepreneurial exit: divergent exit routes and their drivers. Journal of Business Venturing, 25(4), 362-375.

Wennekers, S., van Stel, A., Thurik, R., \& Reynolds, P. (2005). Nascent entrepreneurship and level of economic development. Small Business Economics, 24(3), 293-309.

Wennekers, S., Thurik, R., van Stel, A., \& Noorderhaven, N. (2007). Uncertainty avoidance and the rate of business ownership across 21 OECD countries, 1976-2004. Journal of Evolutionary Economics, 17(2), 133-160.

White, M. J. (2001). Bankruptcy procedures in countries undergoing financial crises. In S. Claessens, S. Djankov, \& A. Mody (Eds.), Resolution of financial distress: an international perspective on the design of bankruptcy laws: 25-45. Washington D.C.: The World Bank.

White, M. J. (2007). Bankruptcy law. In M. A. Polinsky \& S. Shavell (Eds.), Handbook of law and economics (Vol. 2, pp. 1016-1072). Amsterdam: Elsevier.

Wong, P. K., Ho, Y. P., \& Autio, E. (2005). Entrepreneurship, innovation and economic growth: evidence from GEM data. Small Business Economics, 24(3), 193-203. 